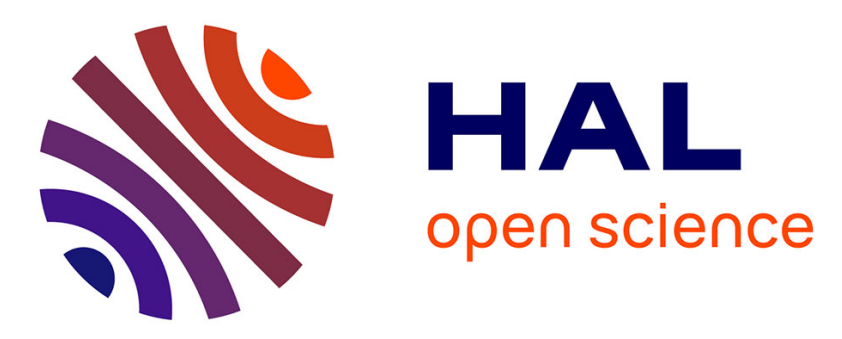

\title{
First Total Syntheses of Novel Non-Enzymatic Polyunsaturated Fatty Acid Metabolites and Their Identification in Edible Oils
}

Tereza Pavlíčková, Valérie Bultel-poncé, Alexandre Guy, Amandine Rocher, Guillaume Reversat, Claire Vigor, Thierry Durand, Jean-marie Galano, Ullrich Jahn, Camille Oger

\section{To cite this version:}

Tereza Pavličková, Valérie Bultel-poncé, Alexandre Guy, Amandine Rocher, Guillaume Reversat, et al.. First Total Syntheses of Novel Non-Enzymatic Polyunsaturated Fatty Acid Metabolites and Their Identification in Edible Oils. Chemistry - A European Journal, 2020, 26 (44), pp.10090-10098. 10.1002/chem.202002138 . hal-03026208

\section{HAL Id: hal-03026208 https://hal.science/hal-03026208}

Submitted on 3 Jun 2021

HAL is a multi-disciplinary open access archive for the deposit and dissemination of scientific research documents, whether they are published or not. The documents may come from teaching and research institutions in France or abroad, or from public or private research centers.
L'archive ouverte pluridisciplinaire HAL, est destinée au dépôt et à la diffusion de documents scientifiques de niveau recherche, publiés ou non, émanant des établissements d'enseignement et de recherche français ou étrangers, des laboratoires publics ou privés. 


\title{
First Total Syntheses of Novel Non-Enzymatic Polyunsaturated Fatty Acid Metabolites and Their Identification in Edible Oils
}

\author{
Tereza Pavlíčková, ${ }^{[a, b, c]}$ Valérie Bultel-Poncé, ${ }^{[a]}$ Alexandre Guy, ${ }^{[a]}$ Amandine Rocher, ${ }^{[a]}$ \\ Guillaume Reversat, ${ }^{[a]}$ Claire Vigor, ${ }^{[a]}$ Thierry Durand, ${ }^{[a]}$ Jean-Marie Galano, ${ }^{*[a]}$ Ullrich Jahn, ${ }^{*[b]}$ \\ and Camille Oger*a]
}

\begin{abstract}
Oxidative stress (OS) is an in vivo process leading to free radical overproduction, which triggers polyunsaturated fatty acid (PUFA) peroxidation resulting in the formation of racemic non-enzymatic oxygenated metabolites. As potential biomarkers of $O S$, their in vivo quantification is of great interest. However, since a large number of isomeric metabolites is formed in parallel, their quantification remains difficult without primary standards. Three new PUFA-metabolites, namely $18-\mathrm{F}_{3 \mathrm{t}}$-isoprostane (IsoP) from eicosapentaenoic acid (EPA), 20- $\mathrm{F}_{4 \mathrm{t}}$-neuroprostane (NeuroP) from docosahex-
\end{abstract}

\section{Introduction}

The discovery of non-enzymatic peroxidation of arachidonic acid (AA) by Morrow et al. thirty years ago opened a new research field in eicosanoids. ${ }^{[1]}$ Unlike the enzymatic biosynthesis of prostaglandins (PGs), the non-enzymatic AA metabolism is driven by reactive oxygen species (ROS), which are over-produced under oxidative stress conditions and can react with $A A$ glycerophospholipids by free radical reaction cascades (similar to PG biosynthesis from free AA) to generate end-metabolism oxylipins like racemic isoprostanes (IsoPs). Nowadays IsoPs are

[a] T. Pavličková, Dr. V. Bultel-Poncé, Dr. A. Guy, A. Rocher, G. Reversat, Dr. C. Vigor, Dr. T. Durand, Dr. J.-M. Galano, Dr. C. Oger

Institut des Biomolécules Max Mousseron

IBMM, CNRS, ENSCM, Faculté de Pharmacie

Université de Montpellier

15 avenue Charles Flahault, BP 14491, 34093 Montpellier Cedex 05 (France)

E-mail:jean-marie.galano@umontpellier.fr camille.oger@umontpellier.fr

[b] T. Pavlíčková, Dr. U. Jahn

Institute of Organic Chemistry and Biochemistry

Czech Academy of Sciences

Flemingovo náměstí 2, 16610 Prague 6 (Czech Republic)

E-mail:jahn@uochb.cas.cz

[c] T. Pavlíčková

Department of Organic Chemistry, Faculty of Science

Charles University

Hlavova 8, 12843 Prague 2 (Czech Republic) aenoic acid (DHA) and $20-\mathrm{F}_{3 \mathrm{t}}$-NeuroP from docosapentaenoic acid $\left(D A_{n-3}\right)$ were synthesized by two complementary synthetic strategies. The first one relied on a racemic approach to $18(R S)-18-\mathrm{F}_{3 \mathrm{t}}$-IsoP using an oxidative radical anion cyclization as a key step, whereas the second used an enzymatic deracemization of a bicyclo[3.3.0]octene intermediate obtained from cyclooctadiene to pursue an asymmetric synthesis. The synthesized metabolites were applied in targeted lipidomics to prove lipid peroxidation in edible oils of commercial nutraceuticals. widely accepted as biomarkers of oxidative stress and participate in several physiological processes. IsoPs have been shown to act as lipid mediators in vasoconstriction and platelet aggregation, and may participate in intracellular signaling through activation of prostanoid receptors. ${ }^{[2]}$ Similar radical oxidation/ cyclization reactions take place with all other PUFAs such as DHA (docosahexaenoic acid, C22:6 n-3), EPA (eicosapentaenoic acid, C20:5 n-3) or DPA ${ }_{n-3}$ (docosapentaenoic acid, C22:5n-3) from the omega-3 family or AdA (adrenic acid, C22:4 n-6) as an omega- 6 PUFA. ${ }^{[3]}$ A large number of cyclic metabolites are formed during lipid peroxidation, which necessitates a classification and specific nomenclature for each family of oxylipins. ${ }^{[4]}$ Thus, cyclic compounds resulting from peroxidation of fatty acids with 18 carbon atoms are called phytoprostanes (PhytoPs), those with 20 carbon atoms IsoPs, and those with 22 carbon atoms neuroprostanes (NeuroPs). They also differ from each other by the number of double bonds. Importantly, each of these multiple individual compounds may have its own biological role(s). We recently demonstrated that a particular isomer of NeuroP from DHA is a powerful anti-arrhythmic compound, $^{[5]}$ an IsoP from EPA is neuroprotective in bovine retina ${ }^{[6]}$ whereas a PhytoP from $\alpha$-linolenic acid (ALA) protects immature neurons from oxidant injury and promotes differentiation of oligodendrocyte progenitors. ${ }^{[7]}$

Our two groups have been working on the synthesis of these non-enzymatic PUFA metabolites for many years and developed diverse individual synthetic strategies but we decided to work together to target new metabolite families. Racemic IsoPs are accessible by Jahn's oxidative cyclization/ $\alpha$-chain attachment strategy (Approach I). ${ }^{[8-10]}$ Since potential specific biological activity is likely inherent to individual enantiomers, 
asymmetric approach based on enzymatic deracemization of bicyclo[3.3.0]octenes developed in the Durand group will serve to access them for in depth study (Approach II). ${ }^{[11,12]}$ Merging the two strategies can be expected to accelerate specification of individual metabolites significantly. Here, we focus our efforts on the synthesis of C20 and C22 metabolites having the 3 -hydroxypentenyl $\omega$-chain as common feature. This includes providing access to one of the major cyclic EPA metabolites, namely $18-\mathrm{F}_{3 \mathrm{t}}$-IsoP (1) to prove its in vivo formation and to further use it as primary standard in targeted lipidomics. Our strategy allows to attach in parallel various $\alpha$-chain modules leading to a unified approach to NeuroP derived from DHA (2) and $\mathrm{DPA}_{n-3}$ (3) using the same precursor (Scheme 1).
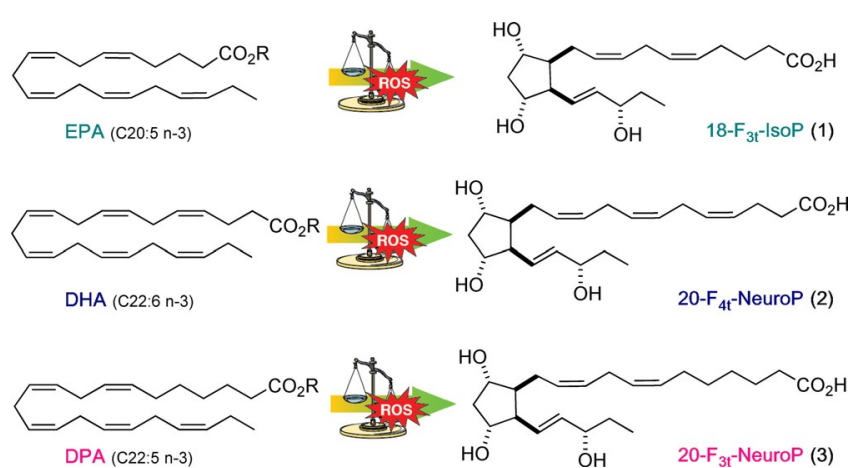

Scheme 1. Formation of the target families of oxylipins.

Here, we report the first total syntheses of racemic $18(R S)$ $18-\mathrm{F}_{3 \mathrm{t}}$-IsoP (rac-1), 18- $\mathrm{F}_{3 \mathrm{t}}$-IsoP $((S)-1)$ and 18-epi-18- $\mathrm{F}_{3 \mathrm{t}}$-IsoP $((R)-$ 1), 20- $\mathrm{F}_{4 \mathrm{t}}-\mathrm{NeuroP}$ and 20-epi-20- $\mathrm{F}_{4 \mathrm{t}}-\mathrm{NeuroP}((S)-2)$ and $((R)-2)$ as well as $20-\mathrm{F}_{3 \mathrm{t}}-\mathrm{NeuroP}$ and $20-e p i-20-\mathrm{F}_{3 \mathrm{t}}-\mathrm{NeuroP}((S)-3)$ and $((R)-$ 3) epimers, respectively. We apply the synthesized cyclic EPA and DHA metabolites as analytical standards to identify the formation of lipid peroxidation metabolites in two encapsulated edible oil nutraceuticals.

\section{Results and Discussion}

\section{Retrosynthetic analysis}

The retrosynthetic analysis of racemic $18(R S)-18-\mathrm{F}_{3 \mathrm{t}}$-IsoP (rac-1, approach I) leads to protected skipped diyne 4 , which can be further simplified by twofold $C(s p 3)-C(s p)$ disconnection to oxygenated cyclopentanecarboxylate $5 \mathrm{a}$, propargylic unit 7 and methyl hex-5-ynoate 8 (Scheme 2). The cyclic intermediate 5 a can be further disconnected to protected 3,5-dihydroxy ester $6 .^{[10]}$

The asymmetric approach II envisioned disconnection of enantiomerically enriched 1, 2 and $\mathbf{3}$ at the (Z)-double bond closest to the ring leading to common enantiomerically enriched 2-hydroxyethylcyclopentane 9 with the $\omega$-chain in place. Further disconnection of the remaining double bond leads to cyclopentane 10, which can be accessed on multigram scale by enzymatic deracemization. ${ }^{[12]}$

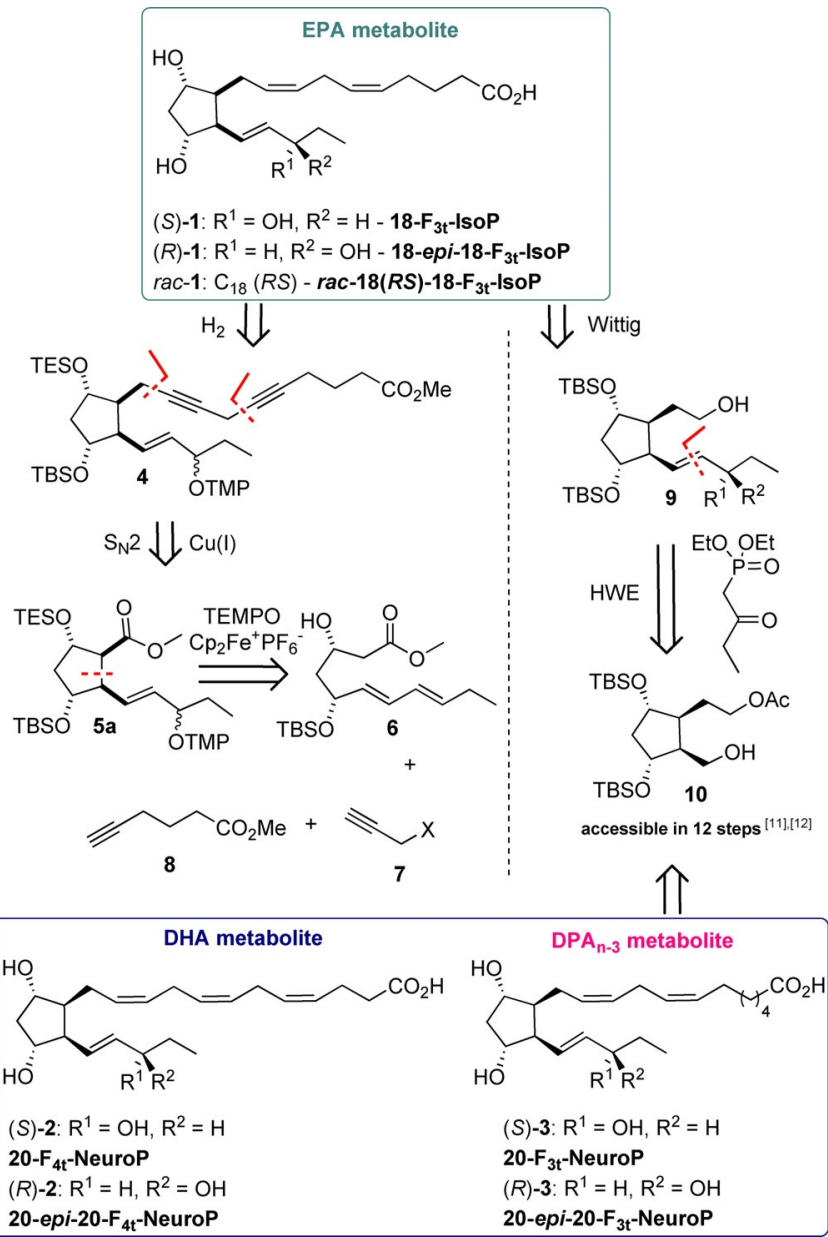

Scheme 2. Retrosynthetic analysis. TMP $=$ 2,2,6,6-tetramethylpiperidin-1-yl.

\section{Approach I: Total synthesis of rac-18(RS)-18- $\mathrm{F}_{3} \mathrm{t}-$ IsoP (rac-1)}

The synthesis commenced with cyclization precursor 6 readily available in three steps in high yield, ${ }^{[10]}$ which was deprotonated by excess LDA in the presence of 8.5 equiv $\mathrm{LiCl}$, followed by oxidative cyclization of the resulting alkoxide enolate trig-

Camille Oger was born in Saint-Gaudens (France). She obtained her PhD from Montpellier 2 University in the field of total synthesis in 2010 and she did postdoctoral work with Pr. Ilan Marek at the Technion- Israel Institute of Technology, working on a new access to polypropionate units. She was promoted assistant professor at Montpellier 1 University in 2011, and obtained her habilitation in 2016 based on her research work on the development of new strategies toward the synthesis of bioactive lipids. In 2017, she received Jean Normant award from the Organic Division of the French Chemical Society. Her research

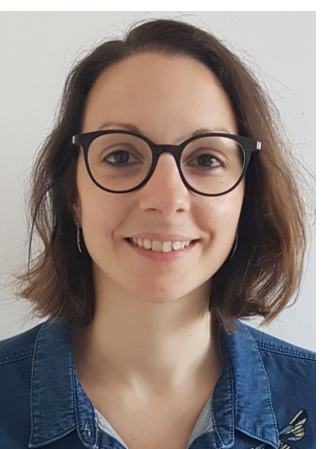
field is at the interface of chemistry and biology, with the total synthesis of lipid metabolites, the quantification of such compounds in biological fluids and the research of potent biological properties. 
gered by ferrocenium hexafluorophosphate and oxygenation by stable free radical TEMPO (Scheme 3). Hydroxycyclopentane carboxylates $11 \mathrm{a}$ and $11 \mathrm{~b}$ were isolated in $63 \%$ yield and slightly improved 2.3:1 diastereoselectivity compared to our previous cyclization conditions. ${ }^{[10]}$

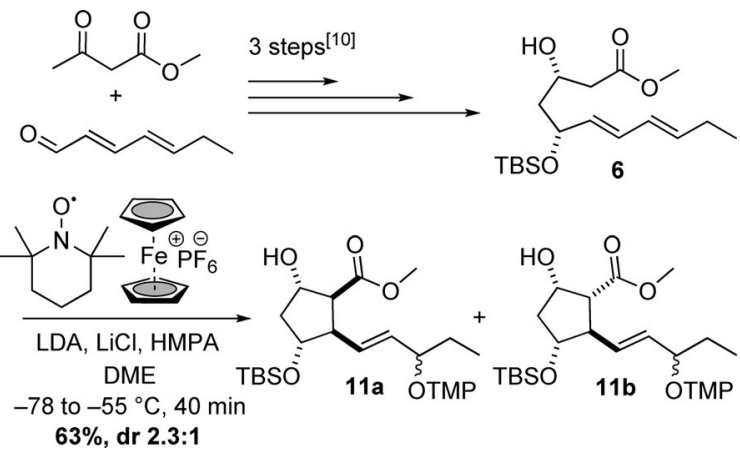

Scheme 3. Synthesis of cyclopentanols $11 \mathrm{a} / 11 \mathrm{~b}$.

Treating the inseparable diastereomeric mixture of $11 \mathrm{a}$ and $11 \mathrm{~b}$ with a strictly equimolar amount of TESCl resulted in the formation of a chromatographically easily separable mixture of $60 \%$ of desired cis-isomer 5 a ( $86 \%$ with respect to 11 a), $15 \%$ of $\mathbf{5} \mathbf{b}$ and $16 \%$ of recovered $\mathbf{1 1} \mathbf{b}$ (Scheme 4). Isolated ester $\mathbf{5 a}$ was reduced by DIBAL-H in high yield and cleanly transformed to the corresponding triflate 13 , thus providing the electrophilic alkylation partner.

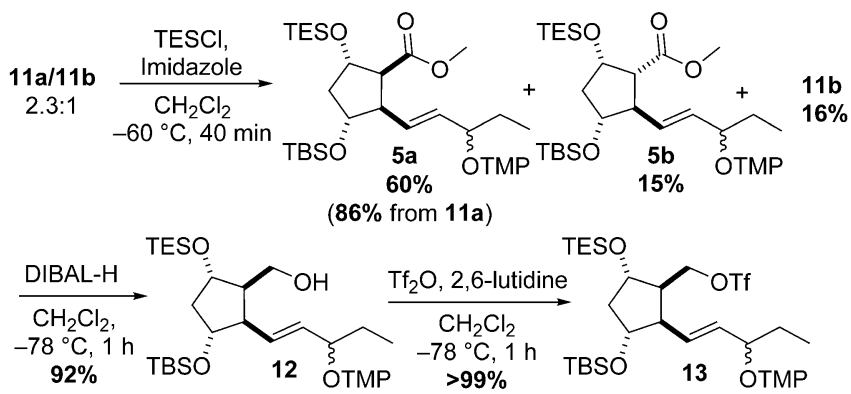

Scheme 4. Preparation of triflate 13 from esters $11 \mathrm{a} / \mathbf{1 1} \mathrm{b}$.

The $\alpha$-chain was connected in a two-step procedure. At first a propargylic unit was installed as a double bond surrogate. Several propargyl precursors were tested (Table 1). PMB-protected propargyl alcohol 7 a was a suitable difunctional reactant. Its deprotonation by $n$ BuLi smoothly proceeded and gave propargylic cyclopentane $\mathbf{1 4}$ a in good yield (entry 1 ), however, the subsequent deprotection of the PMB group (not shown) was not successful. Propargyl alcohol-derived dianion should also give the desired outcome after O- and C-deprotonation, but would still require further transformation of the hydroxy group.

A more direct approach consists of alkylation of propargyl halides, but this requires carefully controlled conditions. In the

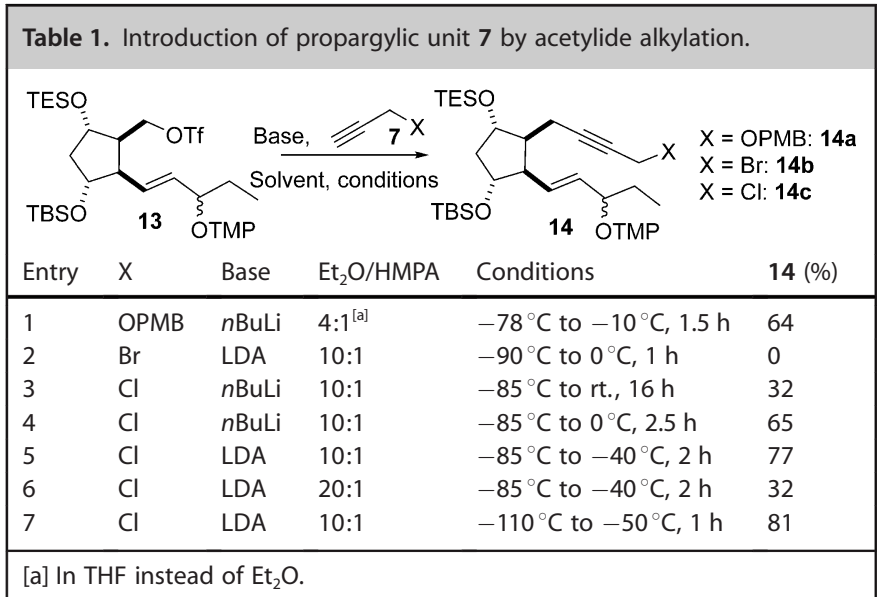

event, when propargyl bromide $\mathbf{7} \mathbf{b}$ was subjected to LDA, the reaction gave a complex mixture of products that further decomposed during column chromatography and (bromobutynyl)cyclopentane $14 \mathbf{b}$ could not be isolated (entry 2 ). In contrast, the use of propargyl chloride $7 \mathrm{c}$ and slow warming was successful albeit in low yield (entry 3 ). Further optimization revealed that shortening the reaction time to $2 \mathrm{~h}$, while warming to $0^{\circ} \mathrm{C}$ significantly improved the yield of (chlorobutynyl)cyclopentane $14 \mathrm{c}$ to an acceptable level (entry 4, 65\% yield). Switching back to LDA and raising the temperature to $-40^{\circ} \mathrm{C}$ over two hours led to further improvement (entry 5, 77\% yield), however decreasing the amount of HMPA resulted in a sharp drop of the yield (entry 6, 32\% yield). Finally, we were pleased to find the optimal conditions, which consisted of deprotonating $7 \mathrm{C}$ at $-110^{\circ} \mathrm{C}$ and raising the reaction temperature to maximally $-50^{\circ} \mathrm{C}$ over an hour, providing $14 \mathrm{c}$ in $81 \%$ yield (entry 7). This transformation might be very useful for constructing other skipped polyyne systems.

Subsequent $\mathrm{Cu}^{\prime}$ mediated $\mathrm{C}-\mathrm{C}$ coupling of 4-cyclopentyl-2butynyl chloride $14 \mathrm{c}$ with 5 -hexynoate $8^{[13]}$ proceeded with good yield and allowed assembly of the full carbon skeleton of ester 4 (Scheme 5). Partial hydrogenation of this fully protected compound was attempted, however, numerous applied conditions gave mixtures of partially, fully and overhydrogenated compounds (not shown).

Our experience suggested that a free hydroxy group might augment the selectivity thanks to better coordination of the

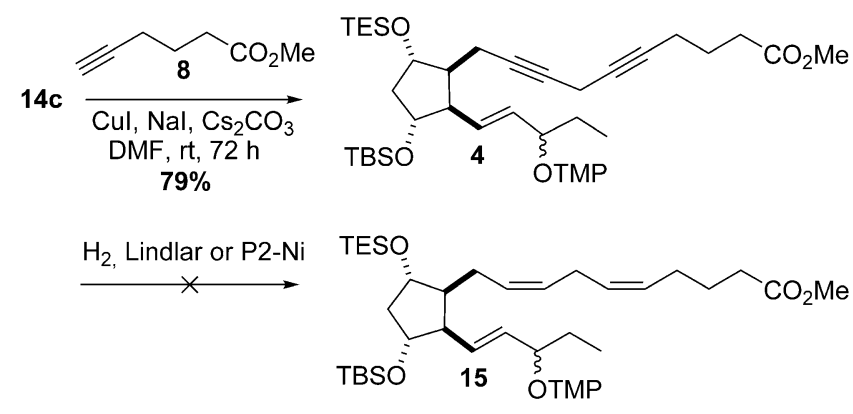

Scheme 5. Cu'-Mediated coupling and failed hydrogenation of diyne 4. 
substrate to the catalyst surface. Therefore, the tetramethylpiperidinyl (TMP) group in diyne ester 4 was cleaved under oxidative conditions affording enone $\mathbf{1 6}$ in very good yield. It should be noted that despite a potential sensitivity of the skipped diyne to the oxidative conditions, a short reaction time guaranteed a clean reaction. Subsequent reduction of the carbonyl group in 16 under Luche conditions furnished allylic hydroxy ester 17 as a 1.2:1 mixture of C-18 epimers in $64 \%$ yield (Scheme 6).
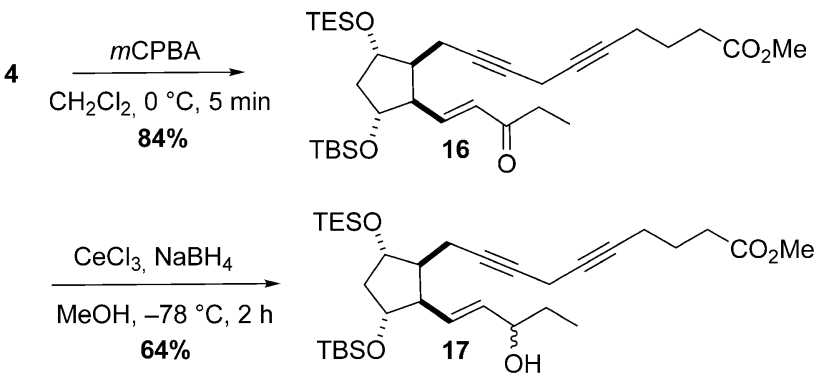

Scheme 6. Oxidative TEMPO deprotection and Luche reduction.

Hydroxydiynoate 17 was subjected to hydrogenation under typical Lindlar conditions (EtOAc/pyridine) ${ }_{1}^{[8]}$ which gratifyingly gave skipped diene $\mathbf{1 8}$ in $\mathbf{7 2} \%$ yield (Scheme 7). Finally, the remaining silyl groups were cleaved with tetrabutylammonium fluoride (TBAF) and final saponification with $\mathrm{LiOH} \cdot \mathrm{H}_{2} \mathrm{O}$ provided racemic $18(R S)-18-\mathrm{F}_{3 \mathrm{t}} \mathrm{IsoP}$ (rac-1) as a partially separable mixture of C-18 epimers. Thus, the total synthesis of rac- 1 was accomplished in $7 \%$ yield over 11 steps from known monoprotected 3,5-dihydroxy ester 6 (5\% over 14 steps in total).
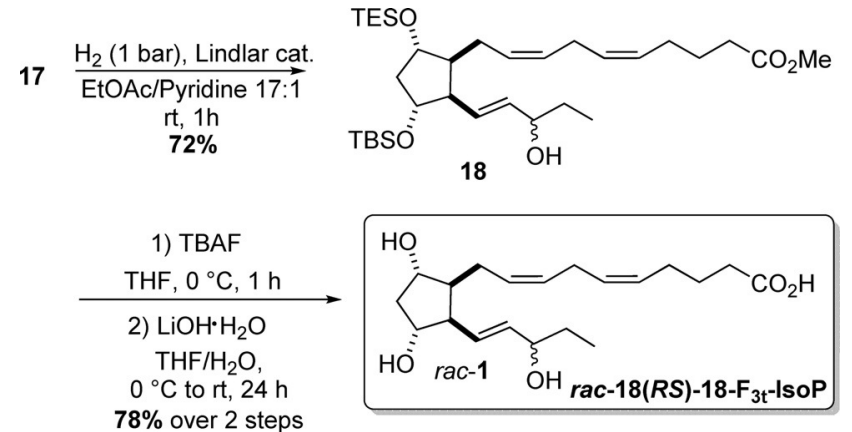

Scheme 7. Hydrogenation of 17 and final deprotection.

Approach II: Asymmetric total syntheses of $18-\mathrm{F}_{3 \mathrm{t}}-\mathrm{IsoP}$, 20- $\mathrm{F}_{4 \mathrm{t}}-\mathrm{NeuroP}$, and 20- $\mathrm{F}_{3 \mathrm{t}}-$ NeuroP (1-3)

The asymmetric syntheses of $18-\mathrm{F}_{3 \mathrm{t}}-\mathrm{IsoP}, 20-\mathrm{F}_{4 \mathrm{t}}-\mathrm{NeuroP}$ and $20-$ $\mathrm{F}_{3 \mathrm{t}}$-NeuroP 1-3 began with the preparation of monoacetylated cyclopentane 10 on gram scale in $10 \%$ overall yield over 12 steps. ${ }^{[11,12]}$ As previously described, enzymatic deracemization using Amano AK lipase permitted access to properly functionalized enantioenriched compound $10{ }^{[11]}$ The $\omega$-chain was subsequently introduced over five steps (Scheme 8). Enone 19<smiles>CC(=O)OCC[C@@H]1[C@@H](CO)[C@H](O[SbH3])C[C@H]1O[SbH3]</smiles>

10

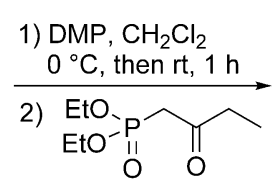

$\mathrm{Ba}(\mathrm{OH})_{2}, \mathrm{THF}, \mathrm{rt}, 16 \mathrm{~h}$
TBSO TBS

$\mathbf{8 7} \%$ over 2 steps

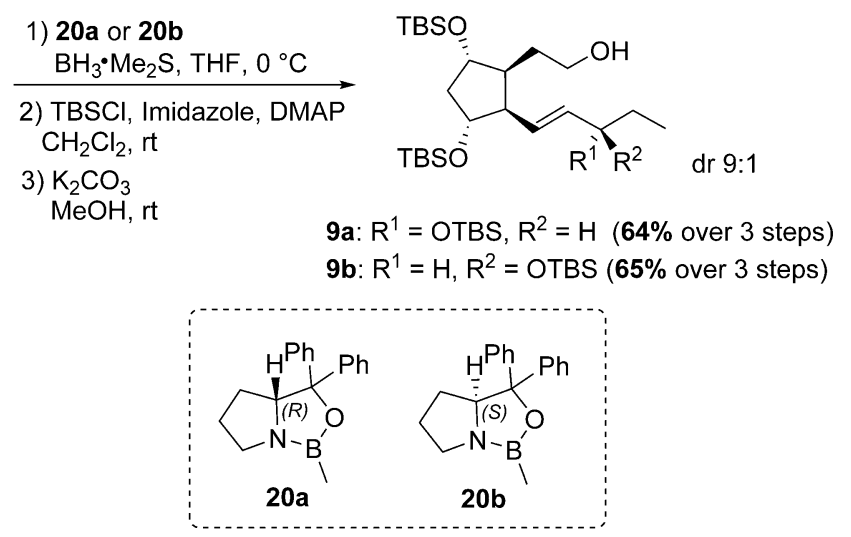

Scheme 8. Preparation of common intermediates $\mathbf{9 a}$ and $\mathbf{9 b}$.

was cleanly prepared in $87 \%$ yield by a two-step sequence consisting of Dess-Martin oxidation of the primary alcohol followed by a Horner-Wadsworth-Emmons (HWE) reaction with dimethyl 2-oxobutylphosphonate using $\mathrm{Ba}(\mathrm{OH})_{2}$ as base under mild conditions to avoid epimerization. ${ }^{[15]}$

The keto group in 19 was subsequently enantioselectively reduced using a Corey-Bakshi-Shibata (CBS) reduction with $(R)-(+)$ - or (S)-(-)-2-methyl-1,3,2-oxazaborolidines $20 \mathrm{a}$ or $20 \mathrm{~b}$. Both, the corresponding $(S)$ - and $(R)$-allylic alcohols were obtained in good yields, each in a 9:1 diastereoisomeric ratio $(d r)$. TBS-protection of the newly formed hydroxy group and acetate deprotection completed the synthesis of common intermediates (S)-9a and (R)-9 b in $64 \%$ and $65 \%$ yield, respectively, over three steps.

With central precursors 9 containing the cyclopentane ring and the $\omega$-chain at hand, the syntheses of EPA, DHA and $\mathrm{DPA}_{\mathrm{n}-3}$ metabolites were pursued, all three following the same synthetic route (Scheme 9). 2-Cyclopentylethanols $9 \mathrm{a}$ and $\mathbf{9 b}$ were first oxidized to the corresponding aldehydes using the Dess-Martin periodinane and subsequently subjected to Wittig reactions to install the $\alpha$-side chain.

The desired phosphonium salts A, B and C, were synthesized in four to six steps, respectively (see the Supporting Information for the synthesis). The corresponding ylides were generated by deprotonation with NaHMDS at low temperature $\left(-50^{\circ} \mathrm{C}\right.$ or $\left.-78^{\circ} \mathrm{C}\right)$ before reaction with the aldehydes derived from $9 \mathrm{a}$ or $9 \mathrm{~b}$. Fully protected derivatives of $18-\mathrm{F}_{3 \mathrm{t}^{-}}-\mathrm{Iso}, 20-\mathrm{F}_{4 \mathrm{t}^{-}}$ NeuroP and $20-F_{3 t}-$ NeuroP $\mathbf{2 1} \mathbf{a}, \mathbf{b}-\mathbf{2 3} \mathbf{a}, \mathbf{b}$ were obtained in moderate to good 22 to $73 \%$ unoptimized yields. The yields of the Wittig reactions were dependent on the nature of the phosphonium salts (see Supporting Information).

With the fully assembled carbon skeleton at hand, final deprotection steps were carried out on compounds 21-23. First, the three silyl groups were hydrolyzed with $0.5 \mathrm{M} \mathrm{HCl}$ in $\mathrm{MeOH}$. To our delight, we were able to separate the approxi- 


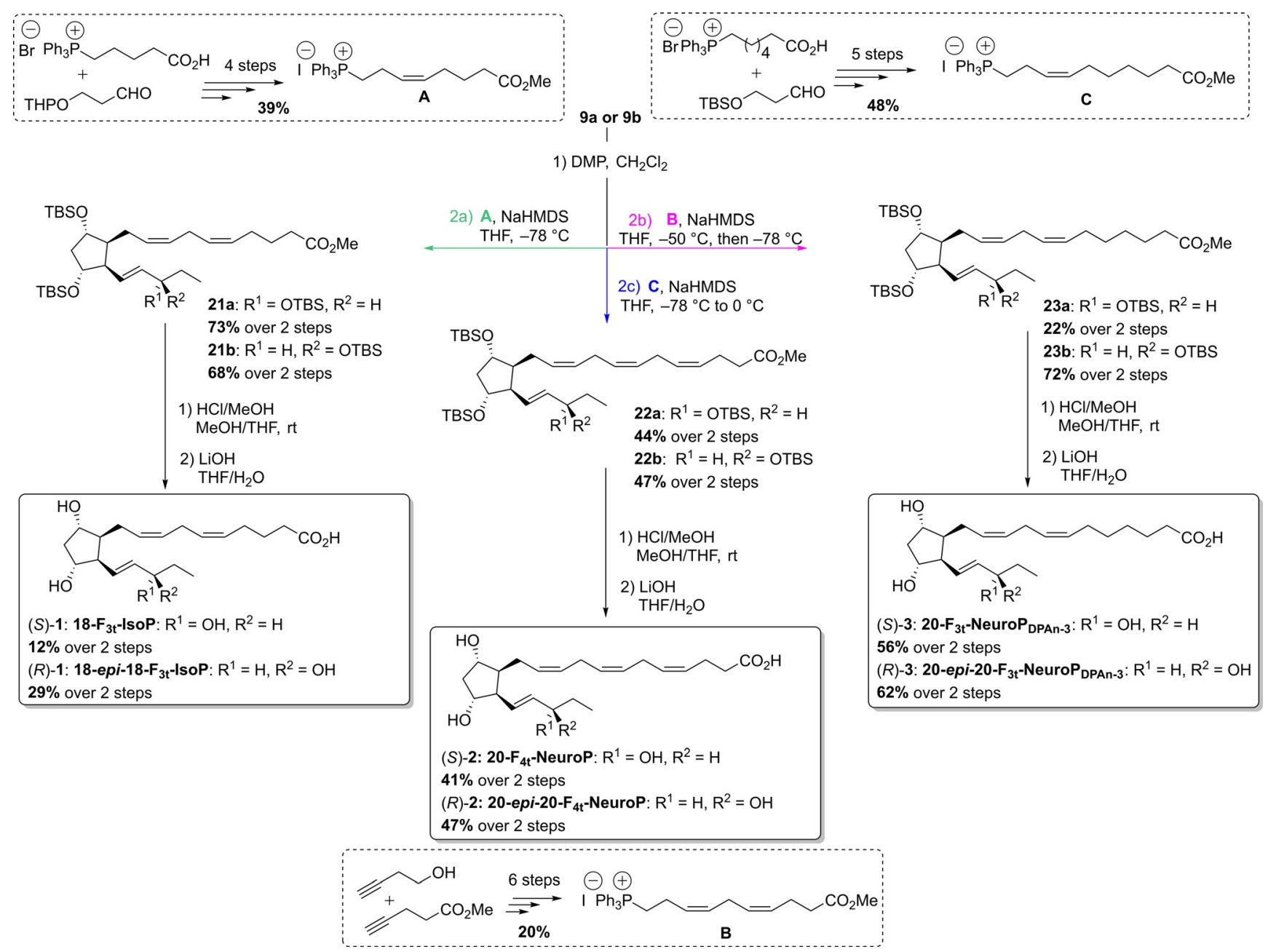

Scheme 9. Asymmetric synthesis of $18-\mathrm{F}_{3 \mathrm{t}}-\mathrm{IsoP}, 20-\mathrm{F}_{4 \mathrm{t}}-\mathrm{NeuroP}$ and $20-\mathrm{F}_{3 \mathrm{t}}-\mathrm{NeuroP}$ and their epimers at the hydroxy group in the $\omega-\mathrm{chain}$.

mately $10 \%$ of undesired epimers carried through from the CBS reductions at this stage by silica gel column chromatography. Partial hydrolysis of the methyl ester to target $20-\mathrm{F}_{3 \mathrm{t}^{-}}$ NeuroP $\mathbf{3}$ was also observed under these conditions. Finally, saponification of the methyl esters using $\mathrm{LiOH} \cdot \mathrm{H}_{2} \mathrm{O}$ provided the individual 18- and 20-epimers of $18-\mathrm{F}_{3 \mathrm{t}^{-}}-\mathrm{IsoP} 1,20-\mathrm{F}_{4 \mathrm{t}^{-}}$ NeuroP 2 and $20-F_{3 t}-$ NeuroP 3 in $12-62 \%$ yield over the two steps. Thus, we obtained compounds $(R)-\mathbf{1}$ in $11 \%$ yield, (S)-1 in $5 \%$ yield, $(R)-2$ in $13 \%$ yield, $(S)-2$ in $10 \%$ yield, $(R)-3$ in $25 \%$ yield, $(S)-3$ in $7 \%$ yield over nine steps from monoacetylated cyclopentane 10.

\section{Quantification of compounds in edible oils}

Almost fifty years ago, Bang and Dyerberg reported low incident rates of cardiovascular diseases in Greenland Inuits who consumed mainly omega-3 fatty acids by intake of seal meat. ${ }^{[16]}$ Since this study and many more, the food supplement industry has developed, among others, capsules rich in omega-3 PUFAs, containing mainly DHA and EPA, extracted from fat fishes or algae. ${ }^{[17]}$ PUFAs have indeed essential physiological roles but are also prone to peroxidation leading to oxy- genated metabolites. Moreover, these PUFA metabolites have found a strong biological interest on their own. ${ }^{[2]}$ As one example, our group recently described the anti-arrhythmic properties of a NeuroP and has shown that this DHA metabolite has a higher activity than DHA itself. ${ }^{[5]}$ Lipid peroxidation of food supplements thus represents a phenomenon not to be neglected. There are several assays to quantify lipid peroxidation reported in the literature including $15-\mathrm{F}_{2 \mathrm{t}}-\mathrm{IsoP}^{[18]}$ However, this arachidonic acid metabolite is not specific to quantify the extent of peroxidation of other PUFA metabolites. Our group is dedicated to the synthesis of oxygenated PUFA metabolites to use them as biomarkers of lipid peroxidation and to highlight their individual biological properties. In this context, we recently developed a targeted lipidomic approach to quantify metabolites of all PUFAs in various matrices. In this work, we studied two commercial dietary supplements encapsulating omega-3 PUFAs stemming from different marine resources: calanus oil from Calanus finmarchicus crustacean (NourSea) and a fish oil mixture from sardine, anchovy, mackerel, and herring (WHC), both containing antioxidant-like compounds (astaxanthin and cholecalciferol, respectively). ${ }^{[19]}$ We applied a targeted lipidomic approach using micro LC-MS/MS, ${ }^{[20]}$ and quantified free metab- 
olites including newly synthesized rac-1, (S)-2 and (R)-2, specific to DHA and EPA peroxidation. ${ }^{[21]}$

Figure 1 represents the sum of the metabolites of DHA (NeuroPs) and EPA (IsoPs) detected, which are depicted as relative percentages (the sum of NeuroPs and IsoPs being 100\%). This shows a higher level of DHA metabolites compared to EPA metabolites in both oils but no significant difference between the two oils.

Figure 2 displays individual DHA and EPA metabolite levels as expressed by percentage of the sum of DHA and EPA metabolites, respectively.

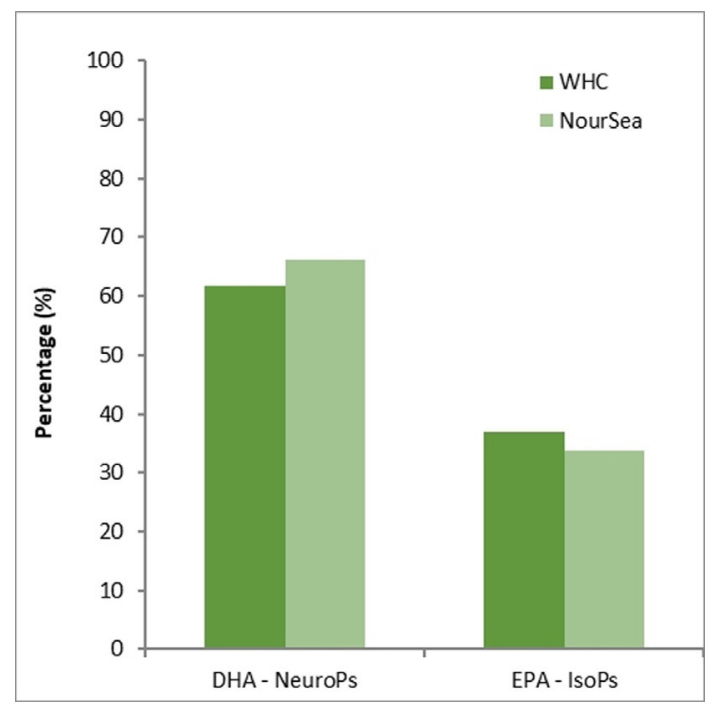

Figure 1. Relative percentage of DHA and EPA derived metabolites in NourSea and WHC oils.

As described in the literature, the 4- and 5-series predominate for DHA and EPA metabolites, respectively. ${ }^{[3 a]}$ Newly synthesized $18-\mathrm{F}_{3 \mathrm{t}}$-IsoP as well as the $20-\mathrm{F}_{4 \mathrm{t}}$-NeuroP were detected in sizeable quantity in both oils. The metabolite profiles vary between the two oils. A broad and relatively even distribution of all $\mathrm{F}_{4}$-NeuroP and $\mathrm{F}_{3}$-IsoP metabolites was found in calanus oil (Noursea), whereas fish oil (WHC) predominately contains 4$\mathrm{F}_{4 \mathrm{t}}-$ NeuroP, $5-\mathrm{F}_{3 \mathrm{t}}-\mathrm{IsoP}$ and small amounts of $13-\mathrm{F}_{4 \mathrm{t}}-$ NeuroP and $18-\mathrm{F}_{3 \mathrm{t}}$-IsoP. Both, natural oil composition and manufacturing process may play a role in this diversity. A preliminary quantification study ranges the DHA metabolites from $3 \mathrm{ngg}^{-1}$ to $230 \mathrm{ngg}^{-1}$ of oil, and EPA metabolites from $26 \mathrm{ngg}^{-1}$ to $36 \mathrm{ng} \mathrm{g}^{-1}$ of oil.

This work is the first to report the detection and quantification of $18-\mathrm{F}_{3 \mathrm{t}}-\mathrm{IsoP}$ and $20-\mathrm{F}_{4 \mathrm{t}}-\mathrm{NeuroP}$ in edible oils thanks to their syntheses. More importantly, this work is the first to demonstrate the presence of several lipid peroxidation metabolites of the isoprostanoid family in food supplements. Among all the metabolites quantified in these two edible oils, we also detected 4(RS)-4- $\mathrm{F}_{4 \mathrm{t}}-$ NeuroP and 5-epi-5- $\mathrm{F}_{3 \mathrm{t}}$-IsoP metabolites, which recently showed anti-arrhythmi ${ }^{[5]}$ and neuroprotective ${ }^{[6]}$ (in bovine retina) properties. We thus have in hands a very useful technique to highlight and quantify lipid peroxidation,

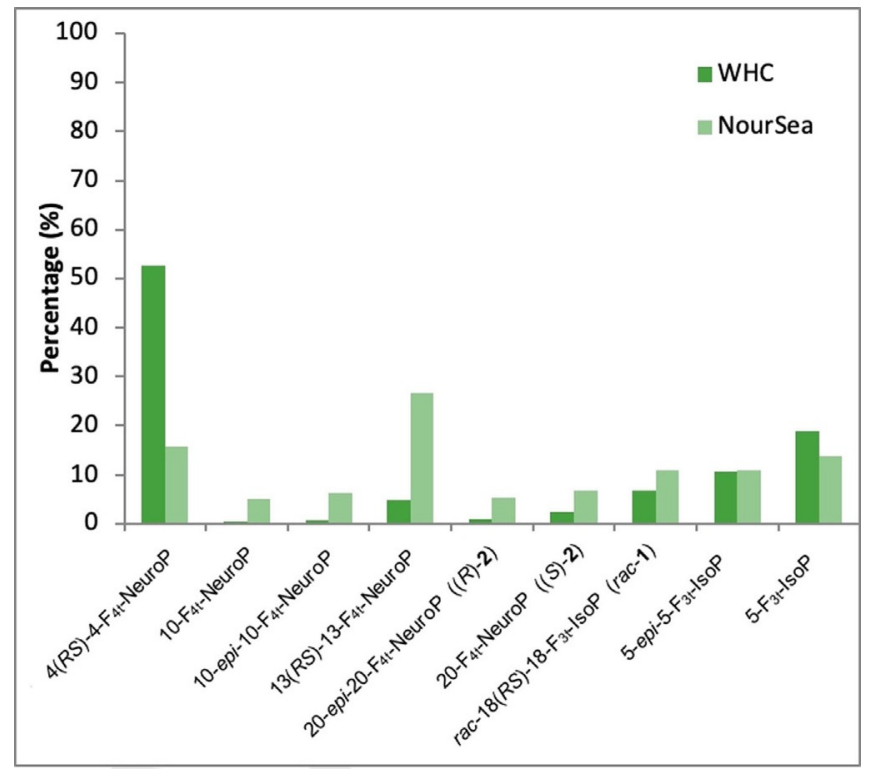

Figure 2. Relative percentage of DHA and EPA derived metabolites in NourSea and WHC oils.

complementary to other existing methods. ${ }^{[18]}$ Moreover, thanks to our database of more than fifty PUFA metabolites including PhytoPs, IsoPs and NeuroPs, our technique is specific to the particular fatty acid contained in these oils or food supplements. As of now, we focus our efforts on the detection of our synthesized metabolites in other food supplements in order to highlight lipid peroxidation of the PUFAs contained in these nutraceuticals.

\section{Conclusions}

In summary, the first total synthesis of racemic $18(R S)-18-\mathrm{F}_{3 \mathrm{t}^{-}}$ isoprostane rac-1 was accomplished in $7 \%$ yield over 11 steps, providing a straightforward approach to this metabolite, which is suitable for determining the global configurational isomer content of the racemic analyte by LC-MS/MS studies. The cyclic core was assembled through an oxidative cyclization strategy; the complex $\alpha$-chain was assembled in two parts by alkylation of a propargylic chloride and Cu'-mediated coupling; final semi-hydrogenation gave the skipped diene skeleton. With this strategy, the total synthesis of 20-NeuroPs becomes feasible by using modified $\alpha$-chain precursors. The orthogonal protection pattern will allow a general access to IsoP and NeuroP classes with hydroxy ketone or enone ring substitution pattern.

The asymmetric total syntheses of $18-\mathrm{F}_{3 \mathrm{t}^{-}}-\mathrm{Iso}$, 18-epi-18- $\mathrm{F}_{3 \mathrm{t}^{-}}$ IsoP, $20-\mathrm{F}_{4 \mathrm{t}}-\mathrm{NeuroP}$ and 20-epi-20- $\mathrm{F}_{4 \mathrm{t}}-\mathrm{NeuroP}$ and $20-\mathrm{F}_{3 \mathrm{t}}-$ NeuroP and 20-epi-20- $\mathrm{F}_{3 \mathrm{t}}$-NeuroP were achieved in nine steps from monoacetate 10 and yields range from 5 to $25 \%$. The cyclopentane ring containing four out of the five stereogenic centers was easily prepared on ten-gram scale. The $\omega$-chain was first installed by HWE reaction, providing a common intermediate from which the various $\alpha$-chains were installed by Wittig reactions with the appropriate phosphonium salts to access the desired target metabolites. Thanks to this highly divergent 
approach, biological evaluation of individual IsoP and NeuroP enantiomers will be possible.

We highlighted the presence of $18-\mathrm{F}_{3 \mathrm{t}^{-}} \mathrm{IsoP}$ and $20-\mathrm{F}_{4 \mathrm{t}^{-}}$ NeuroP in two encapsulated DHA/EPA food supplements. This discovery is evidence of lipid peroxidation, which might have occurred before, during or after encapsulation despite the presence of antioxidants astaxanthin or vitamin D3. More importantly, we report a targeted lipidomic method to quantify lipid peroxidation in oils, which is complementary to the known assays, and may be more specific depending on the PUFA composition of the oils to be studied. Finally, combining the results of targeted lipidomics and the access to individual PUFA metabolites by total syntheses will probably allow much more detailed biological studies of these molecules.

\section{Experimental Section}

\section{Total Syntheses}

rac-18(RS)-18- $\mathrm{F}_{3 \mathrm{t}}$-Isoprostane (rac-1): Disilylated ester 18 (3.0 mg, $6.3 \mu \mathrm{mol})$ was dissolved in dry THF $(250 \mu \mathrm{L})$ under a nitrogen atmosphere, the solution was cooled to $0^{\circ} \mathrm{C}$ and TBAF $(13 \mu \mathrm{L}, 1.0 \mathrm{M}$ in THF, $13 \mu \mathrm{mol}$ ) was dropwise added. The dark yellow solution was stirred at $0^{\circ} \mathrm{C}$ for $1 \mathrm{~h}$ when the reaction was complete as indicated by TLC. The mixture was diluted with HPLC-grade EtOAC ( $3 \mathrm{~mL}$ ), satd. aqueous $\mathrm{NH}_{4} \mathrm{Cl}$ solution $(3 \mathrm{~mL}$ ) was added, the layers were separated and the aqueous was extracted with EtOAc $(3 \times$ $3 \mathrm{~mL}$ ). The combined organic layers were washed with brine, dried $\left(\mathrm{MgSO}_{4}\right)$, filtered and evaporated. The crude trihydroxy ester was dissolved in THF $(125 \mu \mathrm{L})$ and $\mathrm{H}_{2} \mathrm{O}(250 \mu \mathrm{L})$ was added followed by $\mathrm{LiOH} \cdot \mathrm{H}_{2} \mathrm{O}(5.2 \mathrm{mg}, 0.12 \mathrm{mmol})$ at $0^{\circ} \mathrm{C}$. The reaction mixture was warmed to room temperature and stirred for $24 \mathrm{~h}$ when full conversion was indicated by TLC. The mixture was acidified with $1 \mathrm{M}$ $\mathrm{HCl}$ to $\mathrm{pH} 2$ and extracted with HPLC-grade EtOAc $(5 \times 2 \mathrm{~mL})$. The crude product was adsorbed on silica gel and purified by column chromatography (silica gel, HPLC-grade hexane/EtOAc/MeOH gradient 10:1:0 to $0: 10: 1)$ furnishing racemic $18(R S)-18-\mathrm{F}_{3 \mathrm{t}}-\mathrm{IsOP}($ rac -1$)$ (1.7 mg, $4.8 \mu \mathrm{mol}, 78 \%$ over two steps) as a colorless oil and as partially separable 1.2:1 mixture of C-18 epimers as determined by ${ }^{1} \mathrm{H}$ NMR spectroscopy. The relative configuration at $\mathrm{C}-18$ was assigned by comparing the ${ }^{1} \mathrm{H}$ and ${ }^{13} \mathrm{C}$ NMR spectra to those of enantiomerically enriched $(R)-1$ and (S)-1 (vide infra). 18( $\left.R^{*}\right)$-epimer (major): $R_{\mathrm{f}}=0.20$ (EtOAc); ${ }^{1} \mathrm{H}$ NMR $\left(600 \mathrm{MHz}, \mathrm{CD}_{3} \mathrm{OD}\right): \delta=5.56-5.52$ $(\mathrm{m}, 2 \mathrm{H}), 5.45-5.29(\mathrm{~m}, 4 \mathrm{H}), 3.97\left(\mathrm{dt}^{3}{ }^{3} \mathrm{H}_{\mathrm{H}}=7.2,5.0 \mathrm{~Hz}, 1 \mathrm{H}\right), 3.96-$ $3.91(\mathrm{~m}, 1 \mathrm{H}), 3.88\left(\mathrm{dt},{ }^{3} \mathrm{~J}_{\mathrm{H}, \mathrm{H}}=7.8,5.4 \mathrm{~Hz}, 1 \mathrm{H}\right), 2.83\left(\mathrm{dt},{ }^{2} J_{\mathrm{H}, \mathrm{H}}=\right.$ $\left.15.4 \mathrm{~Hz},{ }^{3} J_{\mathrm{H}, \mathrm{H}}=8.1 \mathrm{~Hz}, 1 \mathrm{H}\right), 2.80\left(\mathrm{dt},{ }^{2} J_{\mathrm{H}, \mathrm{H}}=15.4 \mathrm{~Hz},{ }^{3} J_{\mathrm{H}, \mathrm{H}}=8.1 \mathrm{~Hz}\right.$, $1 \mathrm{H}), 2.73-2.62(\mathrm{~m}, 1 \mathrm{H}), 2.487\left(\mathrm{dt}^{2} \mathrm{~J}_{\mathrm{H}, \mathrm{H}}=14.6 \mathrm{~Hz},{ }^{3} \mathrm{~J}_{\mathrm{H}, \mathrm{H}}=7.4 \mathrm{~Hz}, 1 \mathrm{H}\right)$, 2.23-2.12 (m, 3H), 2.12-2.05 (m, 3H), 2.03 (quint, ${ }^{3} \mathrm{~J}_{\mathrm{H}, \mathrm{H}}=6.8 \mathrm{~Hz}, 1 \mathrm{H}$ ), 1.65 (quint, $\left.{ }^{3} \mathrm{~J}_{\mathrm{H}, \mathrm{H}}=7.6 \mathrm{~Hz}, 2 \mathrm{H}\right), 1.61-1.43(\mathrm{~m}, 3 \mathrm{H}), 0.91 \mathrm{ppm}(\mathrm{t}$, $\left.{ }^{3} \mathrm{~J}_{\mathrm{H}, \mathrm{H}}=7.5 \mathrm{~Hz}, 3 \mathrm{H}\right) ;{ }^{13} \mathrm{C} \mathrm{NMR}\left(125 \mathrm{MHz}, \mathrm{CDCl}_{3}\right): \delta=176.2,135.2$, 129.4, 129.0, 128.9, 128.7, 127.54, 76.9, 76.5, 74.04, 53.5, 50.4, 42.23, 32.6, 30.16, 27.2, 26.21, 25.9, 24.38, $9.67 \mathrm{ppm} .18\left(\mathrm{~S}^{*}\right)$-epimer (minor): $R_{\mathrm{f}}=0.25$ (EtOAc 100\%); ${ }^{1} \mathrm{H}$ NMR $\left(600 \mathrm{MHz}, \mathrm{CD}_{3} \mathrm{OD}\right): \delta=5.52-5.49$ $(\mathrm{m}, 2 \mathrm{H}), 5.45-5.29(\mathrm{~m}, 4 \mathrm{H}), 3.98\left(\mathrm{dt}^{3}{ }^{3} \mathrm{H}_{\mathrm{H}}=7.2,5.0 \mathrm{~Hz}\right), 3.96-3.91$ $(\mathrm{m}, 1 \mathrm{H}), 3.88\left(\mathrm{dt},{ }^{3} J_{\mathrm{H}, \mathrm{H}}=7.8,5.4 \mathrm{~Hz}, 1 \mathrm{H}\right), 2.78\left(\mathrm{dt},{ }^{2} J_{\mathrm{H}, \mathrm{H}}=15.4 \mathrm{~Hz}\right.$, $\left.{ }^{3} J_{\mathrm{H}, \mathrm{H}}=8.1 \mathrm{~Hz}, 1 \mathrm{H}\right), 2.76\left(\mathrm{dt}^{2}{ }^{2} \mathrm{H}_{\mathrm{H}, \mathrm{H}}=15.4 \mathrm{~Hz},{ }^{3} J_{\mathrm{H}, \mathrm{H}}=8.1 \mathrm{~Hz}, 1 \mathrm{H}\right), 2.73-$ $2.66(\mathrm{~m}, 1 \mathrm{H}), 2.491\left(\mathrm{dt},{ }^{2} J_{\mathrm{H}, \mathrm{H}}=14.6 \mathrm{~Hz},{ }^{3} J_{\mathrm{H}, \mathrm{H}}=7.4 \mathrm{~Hz}, 1 \mathrm{H}\right), 2.23-2.12$ $(\mathrm{m}, 3 \mathrm{H}), 2.12-2.05(\mathrm{~m}, 3 \mathrm{H}), 2.03$ (quint, $\left.{ }^{3} J_{\mathrm{H}, \mathrm{H}}=6.8 \mathrm{~Hz}, 1 \mathrm{H}\right), 1.65$ (quint, $\left.{ }^{3} J_{\mathrm{H}, \mathrm{H}}=7.6 \mathrm{~Hz}, 2 \mathrm{H}\right), 1.61-1.43(\mathrm{~m}, 3 \mathrm{H}), 0.90 \mathrm{ppm}\left(\mathrm{t},{ }^{3} J_{\mathrm{H}, \mathrm{H}}=\right.$ $7.5 \mathrm{~Hz}, 3 \mathrm{H}) ;{ }^{13} \mathrm{C} \mathrm{NMR} \quad\left(125 \mathrm{MHz}, \mathrm{CDCl}_{3}\right): \delta=176.2,135.2,129.5$, $129.1,128.9,128.8,127.53,76.9,76.5,74.07,53.9,50.4,42.22,32.5$, $30.20,27.1,26.24,25.9,24.43,9.72 \mathrm{ppm}$; IR (film): $v=3624-2435$ (v br), 3352 (br), 3011, 2954, 2927, 2877, 1710, 1457, 1412, 1260, 1145, 1066, 1030, 1003, $970 \mathrm{~cm}^{-1}$; MS (+ESI) $\mathrm{m} / z$ (\%): 375 (100) $[M+$ $\mathrm{Na}^{+}$, (-ESI) $\mathrm{m} / \mathrm{z}$ (\%): 351 (100) $[\mathrm{M}-\mathrm{H}]^{-}$; HRMS (-ESI) $\mathrm{m} / \mathrm{z}$ : calcd for $\mathrm{C}_{20} \mathrm{H}_{32} \mathrm{O}_{5}-\mathrm{H}^{+}: 351.2177[\mathrm{M}-\mathrm{H}]^{-}$, found: 351.2175 ; (+ESI) $\mathrm{m} / \mathrm{z}$ : calcd for $\mathrm{C}_{20} \mathrm{H}_{32} \mathrm{O}_{5}+\mathrm{Na}^{+}: 375.2142[\mathrm{M}+\mathrm{Na}]^{+}$, found: 375.2140 .

18- $\mathrm{F}_{3 \mathrm{t}}$-IsoP ((S)-1): $\mathrm{HCl}(3.5 \mathrm{~mL}, 0.5 \mathrm{~N}$ in $\mathrm{MeOH}, 1.75 \mathrm{mmol})$ was added to a solution of Wittig compound $21 \mathrm{a} \quad(100 \mathrm{mg}$, $0.175 \mathrm{mmol})$ in THF $(20 \mathrm{~mL})$ and $\mathrm{MeOH}(6.5 \mathrm{~mL})$ at $0^{\circ} \mathrm{C}$. The reaction mixture was stirred at room temperature for $2.5 \mathrm{~h}$ until completion. After quenching by a spatula tip of $\mathrm{NaHCO}_{3}$, water $(20 \mathrm{~mL})$ was added and the mixture was extracted with EtOAc $(3 \times 20 \mathrm{~mL})$, the combined organic layers were washed with brine, dried over $\mathrm{MgSO}_{4}$ and the solvents were removed under reduced pressure. The crude product was purified by column chromatography (silica gel, EtOAc) giving $18-\mathrm{F}_{3 \mathrm{t}}$-IsoP methyl ester $(20 \mathrm{mg}, 32 \%$ ) as $>95: 5$ diastereomeric mixture as determined by ${ }^{1} \mathrm{H}$ NMR spectroscopy as a colorless oil. $R_{\mathrm{f}}=0.36(\mathrm{EtOAc}) ;[\alpha]_{\mathrm{D}}^{20}=+9.5(c=0.2$ in $\mathrm{MeOH})$; ${ }^{1} \mathrm{H}$ NMR $\left(300 \mathrm{MHz}, \mathrm{CD}_{3} \mathrm{OD}\right): \delta=5.57-5.48(\mathrm{~m}, 2 \mathrm{H}), 5.48-5.25(\mathrm{~m}$, $4 \mathrm{H}), 4.02-3.83(\mathrm{~m}, 3 \mathrm{H}), 3.65(\mathrm{~s} ; 3 \mathrm{H}), 2.84-2.62(\mathrm{~m}, 3 \mathrm{H}), 2.58-2.42$ $\left(\mathrm{dt},{ }^{2} J_{\mathrm{H}, \mathrm{H}}=14.4 \mathrm{~Hz},{ }^{3} J_{\mathrm{H}, \mathrm{H}}=7.4 \mathrm{~Hz}, 1 \mathrm{H}\right), 2.33\left(\mathrm{t},{ }^{3} J_{\mathrm{H}, \mathrm{H}}=7.4 \mathrm{~Hz}, 2 \mathrm{H}\right)$, 2.23-1.97 (m, 5H), 1.67 (quint, $\left.{ }^{3} J_{\mathrm{H}, \mathrm{H}}=7.6 \mathrm{~Hz}, 2 \mathrm{H}\right), 1.61-1.43(\mathrm{~m}, 3 \mathrm{H})$, $0.90 \mathrm{ppm} \quad\left(\mathrm{t},{ }^{3} \mathrm{~J}_{\mathrm{H}, \mathrm{H}}=7.4 \mathrm{~Hz}, 3 \mathrm{H}\right) ;{ }^{13} \mathrm{C}$ NMR $\left(75 \mathrm{MHz}, \mathrm{CD}_{3} \mathrm{OD}\right): \delta=$ 175.8, 136.6, 130.6, 130.0, 129.9, 129.7, 129.6, 76.3, 76.2, 75.1, 53.8, 52.0, 51.3, 43.6, 34.1, 31.2, 27.51, 27.46, 26.7, 25.9, 10.3 ppm; MS (+ESI) m/z: $389[\mathrm{M}+\mathrm{Na}]^{+}$; HRMS (+ESI): $\mathrm{m} / \mathrm{z}$ calcd for: $\mathrm{C}_{21} \mathrm{H}_{34} \mathrm{O}_{5}+\mathrm{Na}^{+}: 389.2298[\mathrm{M}+\mathrm{Na}]^{+}$, found: 389.2305 .

$\mathrm{LiOH} \cdot \mathrm{H}_{2} \mathrm{O}(14 \mathrm{mg}, 0.33 \mathrm{mmol})$ was added to a solution of the above prepared $18-\mathrm{F}_{3 \mathrm{t}}$-IsoP methyl ester $(20 \mathrm{mg}, 54 \mu \mathrm{mol})$ in THF $(1 \mathrm{~mL})$ and water $(1 \mathrm{~mL})$ and the reaction mixture was stirred at room temperature for $3 \mathrm{~h}$. The reaction was quenched by slow addition of aqueous $\mathrm{NaHSO}_{4}$ solution $(1 \mathrm{M})$ until the $\mathrm{pH}$ was acidic. The mixture was extracted with EtOAc $(3 \times 2 \mathrm{~mL})$, the combined organic layers were washed with brine $(2 \mathrm{~mL})$, dried over $\mathrm{MgSO}_{4}$ and concentrated in vacuum. The crude product was purified by column chromatography (silica gel, EtOAc) affording $18-\mathrm{F}_{3 \mathrm{t}} \mathrm{IsoP}(S)$ $1(7 \mathrm{mg}, 37 \%)$ as a colorless oil. $R_{\mathrm{f}}=0.28(\mathrm{EtOAc} / \mathrm{MeOH}$ 9:1); $[\alpha]_{D}{ }^{20}=+23.3(c=0.06$ in $\mathrm{MeOH}) ;{ }^{1} \mathrm{H}$ NMR $\left(300 \mathrm{MHz}, \mathrm{CD}_{3} \mathrm{OD}\right): \delta=$ 5.54-5.49 (m, 2H), 5.46-5.31 (m, 4H), 4.01-3.83 (m, 3H), 2.87-2.76 $(\mathrm{m}, 2 \mathrm{H}), 2.76-2.63(\mathrm{~m}, 1 \mathrm{H}), 2.49\left(\mathrm{dt},{ }^{2} \mathrm{~J}_{\mathrm{H}, \mathrm{H}}=14.2 \mathrm{~Hz},{ }^{3} \mathrm{~J}_{\mathrm{H}, \mathrm{H}}=7.3 \mathrm{~Hz}\right.$, $1 \mathrm{H}$ ), $2.30\left(\mathrm{t},{ }^{3} \mathrm{~J}_{\mathrm{H}, \mathrm{H}}=7.4 \mathrm{~Hz}, 2 \mathrm{H}\right), 2.21-1.97(\mathrm{~m}, 5 \mathrm{H}), 1.66$ (quint, ${ }^{3} \mathrm{~J}_{\mathrm{H}, \mathrm{H}}=$ $7.3 \mathrm{~Hz}, 2 \mathrm{H}), 1.60-1.42(\mathrm{~m}, 3 \mathrm{H}), 0.91 \mathrm{ppm}\left(\mathrm{t},{ }^{3} \mathrm{H}_{\mathrm{H}}=7.5 \mathrm{~Hz}, 3 \mathrm{H}\right)$; ${ }^{13} \mathrm{C}$ NMR $\left(75 \mathrm{MHz}, \mathrm{CD}_{3} \mathrm{OD}\right): \delta=177.4,136.6,130.6,130.00,129.98$, 129.7, 76.3, 76.2, 75.1, 53.8, 51.3, 43.5, 34.4, 31.2, 27.6, 27.5, 26.7, 26.0, $10.3 \mathrm{ppm}$; MS (-ESI) m/z: $351[\mathrm{M}-\mathrm{H}]^{-}$; HRMS (-ESI): $\mathrm{m} / \mathrm{z}$ calcd for $\mathrm{C}_{20} \mathrm{H}_{32} \mathrm{O}_{5}-\mathrm{H}^{+}: 351.2177[M-\mathrm{H}]^{-}$, found: 351.2172.

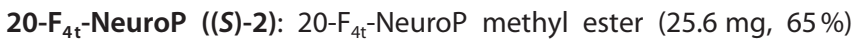
was prepared in analogy to $18-\mathrm{F}_{3 \mathrm{t}} \mathrm{I}-\mathrm{soP}$ methyl ester from ester $22 \mathrm{a}$ (73.7 mg, $0.1 \mathrm{mmol}$ ) as a colorless oil of $>95: 5$ diastereomeric mixture (determined by ${ }^{1} \mathrm{H} N M R$ spectroscopy). $R_{\mathrm{f}}=0.11 \quad$ (EtOAc); $[\alpha]_{D}^{20}=-7.0\left(c=0.2\right.$ in $\left.\mathrm{CHCl}_{3}\right) ;{ }^{1} \mathrm{H}$ NMR $\left(300 \mathrm{MHz}, \mathrm{CDCl}_{3}\right): \delta=5.62-$ $5.43(\mathrm{~m}, 2 \mathrm{H}), 5.43-5.26(\mathrm{~m}, 6 \mathrm{H}), 4.06-3.85(\mathrm{~m}, 3 \mathrm{H}), 3.65(\mathrm{~s} ; 3 \mathrm{H})$, $3.00(\mathrm{br} \mathrm{s} ; 1 \mathrm{H}), 2.89-2.62(\mathrm{~m}, 5 \mathrm{H}), 2.58-2.26(\mathrm{~m}, 6 \mathrm{H}), 2.19-2.06(\mathrm{~m}$, $1 \mathrm{H}), 2.06-1.96(\mathrm{~m}, 2 \mathrm{H}), 1.91(\mathrm{br} s ; 1 \mathrm{H}), 1.69-1.41(\mathrm{~m}, 3 \mathrm{H})$, $0.87 \mathrm{ppm}\left(\mathrm{t},{ }^{3} \mathrm{H}_{\mathrm{H}, \mathrm{H}}=7.4 \mathrm{~Hz}, 3 \mathrm{H}\right) ;{ }^{13} \mathrm{C} \mathrm{NMR}\left(75 \mathrm{MHz}, \mathrm{CDCl}_{3}\right): \delta=173.9$, $135.9,129.7,129.3,129.1,128.5,128.2,128.0,127.8,76.3,76.2,74.3$, 53.5, 51.7, 50.8, 42.3, 34.0, 30.1, 27.0, 25.8, 25.6, 22.8, 9.8 ppm; MS (+ESI) $\mathrm{m} / \mathrm{z}: 375\left[\mathrm{M}+\mathrm{H}-\mathrm{H}_{2} \mathrm{O}\right]^{+}$; HRMS (+ESI): $\mathrm{m} / \mathrm{z}$ calcd for $\mathrm{C}_{23} \mathrm{H}_{36} \mathrm{O}_{5}+\mathrm{H}^{+}-\mathrm{H}_{2} \mathrm{O}: 375.2530\left[\mathrm{M}+\mathrm{H}-\mathrm{H}_{2} \mathrm{O}\right]^{+}$, found: 375.2533 .

$20-\mathrm{F}_{4 \mathrm{t}}-$ NeuroP (34.2 $\mathrm{mg}, 63 \%$ ) was prepared in analogy to (S)-1 from $20-\mathrm{F}_{4 \mathrm{t}}-\mathrm{NeuroP}$ methyl ester $(55 \mathrm{mg}, 0.14 \mathrm{mmol}$ ) as a colorless oil. $R_{\mathrm{f}}=0.48(\mathrm{EtOAc} / \mathrm{HCOOH} 9: 1) ;[\alpha]_{\mathrm{D}}{ }^{20}=+12.6(c=0.5 \mathrm{in} \mathrm{MeOH})$; ${ }^{1} \mathrm{H}$ NMR $\left(300 \mathrm{MHz}, \mathrm{CD}_{3} \mathrm{OD}\right): \delta=5.58-5.47(\mathrm{~m}, 2 \mathrm{H}), 5.45-5.22(\mathrm{~m}$, $6 \mathrm{H}), 4.00-3.79(\mathrm{~m}, 3 \mathrm{H}), 2.89-2.73(\mathrm{~m}, 4 \mathrm{H}), 2.71-2.61(\mathrm{~m}, 1 \mathrm{H}), 2.47$ 
(quint, $\left.{ }^{3} \mathrm{~J}_{\mathrm{H}, \mathrm{H}}=7.4 \mathrm{~Hz}, 1 \mathrm{H}\right), 2.40-2.23(\mathrm{~m}, 4 \mathrm{H}), 2.23-1.98(\mathrm{~m}, 3 \mathrm{H})$, $1.61-1.39(\mathrm{~m}, \quad 3 \mathrm{H}), \quad 0.91 \mathrm{ppm} \quad\left(\mathrm{t}, \quad{ }^{3} \mathrm{H}_{\mathrm{H}}=7.4 \mathrm{~Hz}, \quad 3 \mathrm{H}\right) ;{ }^{13} \mathrm{C}$ NMR (75 MHz, $\mathrm{CD}_{3} \mathrm{OD}$ ): $\delta=177.1,136.6,130.6,130.2,129.8,129.6,129.3$, 129.1, 76.3, 76.2, 75.1, 53.8, 51.3, 43.5, 35.1, 31.2, 27.5, 26.7, 26.5, 23.9, $10.3 \mathrm{ppm}$; MS (+ESI) $\mathrm{m} / \mathrm{z}: 401[\mathrm{M}+\mathrm{Na}]^{+}$; HRMS (+ESI): $\mathrm{m} / \mathrm{z}$ calcd for $\mathrm{C}_{22} \mathrm{H}_{34} \mathrm{O}_{5}+\mathrm{Na}^{+}: 401.2300[\mathrm{M}+\mathrm{Na}]^{+}$, found: 401.2301 .

20- F $_{3 \mathrm{t}}$-NeuroP ((S)-3): $20-\mathrm{F}_{3 \mathrm{t}}-$ NeuroP methyl ester (25 mg, 93\%) was prepared in analogy to $18-\mathrm{F}_{3 \mathrm{t}}$-IsoP methyl ester from silylated ester 23 a $(50 \mathrm{mg}, 0.068 \mathrm{mmol}$ ) as $>95: 5$ diastereomeric mixture (determined by ${ }^{1} \mathrm{H}$ NMR spectroscopy) as a colorless oil. $[\alpha]_{D}{ }^{20}=+2.2 \quad(c=0.2$ in $\mathrm{MeOH}) ;{ }^{1} \mathrm{H}$ NMR $\left(300 \mathrm{MHz}, \mathrm{CD}_{3} \mathrm{OD}\right): \delta$ $=5.60-5.49(\mathrm{~m}, 2 \mathrm{H}), 5.47-5.26(\mathrm{~m}, 4 \mathrm{H}), 3.96-3.63(\mathrm{~m}, 3 \mathrm{H}), 3.65(\mathrm{~s}$; $3 \mathrm{H}), 2.85-2.65(\mathrm{~m}, 3 \mathrm{H}), 2.49\left(\mathrm{dt}^{2}{ }^{2} \mathrm{H}_{\mathrm{H}}=14.6 \mathrm{~Hz},{ }^{3} \mathrm{~J}_{\mathrm{H}, \mathrm{H}}=7.4 \mathrm{~Hz}, 1 \mathrm{H}\right)$, $2.32\left(\mathrm{t},{ }^{3} \mathrm{~J}_{\mathrm{H}, \mathrm{H}}=7.4 \mathrm{~Hz}, 2 \mathrm{H}\right), 2.17-1.73(\mathrm{~m}, 5 \mathrm{H}), 1.66-1.42(\mathrm{~m}, 5 \mathrm{H})$, $1.38-1.30(\mathrm{~m}, 4 \mathrm{H}), 0.91 \mathrm{ppm}\left(\mathrm{t},{ }^{3} \mathrm{~J}_{\mathrm{H}, \mathrm{H}}=7.4 \mathrm{~Hz}, 3 \mathrm{H}\right)$; MS (+ESI) $\mathrm{m} / \mathrm{z}$ : $417[\mathrm{M}+\mathrm{Na}]^{+} ; \operatorname{HRMS}(+\mathrm{ESI}): \mathrm{m} / z$ calcd for $\mathrm{C}_{23} \mathrm{H}_{38} \mathrm{O}_{5}+\mathrm{Na}^{+}$: 417.2611 $[\mathrm{M}+\mathrm{Na}]^{+}$, found: 417.2617 .

$20-\mathrm{F}_{3 \mathrm{t}}$-NeuroP (S)-3 (15 mg, 60\%) was prepared in analogy to (S)-1 from $20-\mathrm{F}_{3 \mathrm{t}}$-NeuroP methyl ester $(26 \mathrm{mg}, 0.066 \mathrm{mmol}$ ) as a colorless oil. $[\alpha]_{D}{ }^{20}=+2.7(c=0.2$ in $\mathrm{MeOH}) ;{ }^{1} \mathrm{H}$ NMR $\left(500 \mathrm{MHz}, \mathrm{CD}_{3} \mathrm{OD}\right): \delta=$ 5.57-5.47 (m, 2H), 5.44-5.34 (m, 4H), 3.98-3.86 (m, 3H), 2.85-2.68 $(\mathrm{m}, 3 \mathrm{H}), 2.53-2.44(\mathrm{~m}, 1 \mathrm{H}), 2.28\left(\mathrm{t}^{3} \mathrm{~J}_{\mathrm{H}, \mathrm{H}}=7.4 \mathrm{~Hz}, 2 \mathrm{H}\right), 2.18-2.04(\mathrm{~m}$, $5 \mathrm{H}), 1.68-1.42(\mathrm{~m}, 5 \mathrm{H}), 1.41-1.30(\mathrm{~m}, 4 \mathrm{H}), 0.91 \mathrm{ppm}\left(\mathrm{t},{ }^{3} \mathrm{~J}_{\mathrm{H}, \mathrm{H}}=\right.$ $7.4 \mathrm{~Hz}, 3 \mathrm{H}) ;{ }^{13} \mathrm{C}$ NMR $\left(125 \mathrm{MHz}, \mathrm{CD}_{3} \mathrm{OD}\right): \delta=176.8,136.6,130.6$, 130.9, 129.8, 129.6, 129.1, 76.3, 76.2, 75.1, 53.8, 51.3, 43.6, 35.2, 31.3, 30.5, 29.9, 28.1, 27.5, 26.8, 26.1, 10.3 ppm; MS (-ESI) m/z: 379 $[M-H]^{-}$; HRMS (-ESI) calcd for $\mathrm{C}_{22} \mathrm{H}_{36} \mathrm{O}_{5}-\mathrm{H}^{+}: 379.2490[\mathrm{M}-\mathrm{H}]^{-}$, found: 379.2484 .

\section{Identification of DHA and EPA metabolites in edible oils}

Oil from food supplement capsules sampling: Food supplement capsules were delivered from their respective manufacturers. Capsules "UnoCardio 1000 + Vitamin D1000" from WHC Health Consulting, ingredients: rTriglyceride (95\% Omega-3; $1200 \mathrm{mg}$ ) EPA $(675 \mathrm{mg}), \mathrm{DHA}(460 \mathrm{mg})$, vitamin $\mathrm{D}_{3}(1000 \mathrm{UI})$. Capsules "NourSea Calanus ${ }^{\circ}$ oil" from NourSea Calanus ${ }^{\circ}$, ingredients: sea natural plankton lipid extract of calanus oil (Calanus finmarchicus, $500 \mathrm{mg}$ ) containing wax esters $(425 \mathrm{mg})$; among these unsaturated fatty acids (145 mg) including omega-3 PUFA (105 mg), astaxanthin $(300 \mu \mathrm{g})$. Capsules were incised using a needle and the oily content was extracted by simple pressure of fingers into a glass vessel. Extraction of lipids: After lipid extraction, oxidative damage was measured by determining the isoprostanoid levels in oily extracts based on micro-LC-MS/MS. Note that each type of sample has been subject to a technical triplicate (e.g. three capsules for each edible oils).

Briefly, the oily extract $(250 \mathrm{mg})$ was mixed with hexane $(5 \mathrm{~mL})$, $\mathrm{MeOH}(2 \mathrm{~mL})$, internal standards (IS; mixture $1 / 1 / 1 / 1$ of deuteriumisotopic $\mathrm{d}_{4}-10(R)-10 \mathrm{~F}_{4 \mathrm{t}}-\mathrm{NeuroP} / \mathrm{d}_{4}-15-\mathrm{F}_{2 \mathrm{t}}-\mathrm{IsoP}$ and $\mathrm{C} 21-15-\mathrm{F}_{2 \mathrm{t}}-\mathrm{IsoP} /$ C19-16- $F_{1 t}-$ PhytoP, $4 \mathrm{ng}$ ) and the mixture was vortexed for $15 \mathrm{~s}$. The material was supplemented with formic acid $(40 \mathrm{~mm}, \mathrm{pH} 4.6 ; 2 \mathrm{~mL})$ before centrifugation at $2000 \mathrm{rpm}$ at room temperature for $5 \mathrm{~min}$. The supernatant was separated and the lower phase was loaded on cartridges (SPE Oasis MAX, 3cc, $60 \mathrm{mg}$, Waters, Milford, MA, USA) previously conditioned by $\mathrm{MeOH}(2 \mathrm{~mL})$ and equilibrated with formic acid ( $20 \mathrm{~mm}, \mathrm{pH} 4.5 ; 2 \mathrm{~mL})$. The cartridges were successively washed with: aqueous $\mathrm{NH}_{3}$ (2 vol.\%; $\left.2 \mathrm{~mL}\right)$, formic acid $(20 \mathrm{~mm}) / \mathrm{MeOH}(70: 30 ; 2 \mathrm{~mL})$, hexane $(2 \mathrm{~mL})$ and hexane/ethyl acetate $(70: 30 ; 2 \mathrm{~mL})$. Targeted metabolites were eluted with hexane/ ethanol/acetic acid (70:29.4:0.6; $2 \mathrm{~mL})$. The eluates were concentrated to dryness under a nitrogen flow at $40^{\circ} \mathrm{C}$. Solutions were reconstituted by addition of aqueous formic acid $(0.1 \mathrm{vol} . \%) / \mathrm{CH}_{3} \mathrm{CN}$
$(83: 17 ; 100 \mu \mathrm{L})$ prior to injection in the microLC-QTRAP ${ }^{\circledR}$ system. Hexane, $\mathrm{NH}_{4} \mathrm{OH}$, EtOAc, formic acid, and EtOH were HPLC grade chemicals. $\mathrm{MeOH}, \mathrm{H}_{2} \mathrm{O}$, acetic acid and $\mathrm{CH}_{3} \mathrm{CN}$ were LCMS grade chemicals.

Liquid chromatography tandem mass spectrometry analysis: Oxidized lipid products were analyzed according to the method previously reported. ${ }^{[20]}$ Briefly, samples were analyzed using a micro liquid chromatography (Eksigent ${ }^{\circ}$ MicroLC 200 plus; Eksigent Technologies, CA, USA) equipped with an autosampler (CTC Analytics AG Zwingen, Switzerland). The autosampler vial tray was kept at $10^{\circ} \mathrm{C}$ and the column (HALO C18 $100 \times 0.5 \mathrm{~mm}, 2.7 \mu \mathrm{m}$, Eksigent Technologies, CA, USA) was set at $40^{\circ} \mathrm{C}$. The mobile phase consisted of a binary gradient of solvent $\mathrm{A}$ (aqueous formic acid, $0.1 \% \mathrm{v} /$ v) and solvent $\mathrm{B}\left(\mathrm{CH}_{3} \mathrm{CN} / \mathrm{MeOH} 8: 2\right)$. The gradient elution program was performed as follows: $17 \%$ solvent $B$ at 0 min until $1.6 \mathrm{~min}$, then $21 \%$ solvent $B$ at $2.8 \mathrm{~min}, 25 \%$ solvent $B$ at $7.3 \mathrm{~min}, 28.5 \%$ solvent $B$ at $8.8 \mathrm{~min}, 33.1 \%$ solvent $B$ at $9.6 \mathrm{~min}, 33.3 \%$ solvent $B$ at $10.9 \mathrm{~min}, 40 \%$ solvent $B$ at $15 \mathrm{~min}$ and $95 \%$ solvent $B$ at $16.5 \mathrm{~min}$ for $2.5 \mathrm{~min}$ and returned to the initial conditions. The sample $(5 \mu \mathrm{L})$ was injected and eluted at a flow rate of $0.03 \mathrm{~mL} \mathrm{~min}^{-1}$. A SCIEX QTRAP ${ }^{\circledR} 5500$ mass spectrometer (Sciex Applied Biosystems) was used to analyze isoprostanoids. The ionization source was an electrospray (ESI), operated in the negative mode. The source voltage was kept at $-4.5 \mathrm{kV}$ and nitrogen was used as curtain gas. MRM analysis was conducted by monitoring transitions from the precursor ion. Data processing was performed by MultiQuant 3.0 software (Sciex Applied Biosystems). Isoprostanoid quantification was based on the analyte to IS ratio using external calibration curves, which were calculated by linear regression of at least six standard concentrations. All data were expressed in relative percentage of the analytes because we were unable to perform spiked experiments in order to calculate matrix effect and extraction yield.

\section{Acknowledgements}

Generous financial support by IOCB Prague (RVO: 61388963) and the Gilead Sciences \& IOCB Research Center (GSRC III) is gratefully acknowledged. The authors are grateful to the French Embassy in Prague for the French government grant to T.P. We thank the University of Montpellier (UM) and the Ecole Doctorale Science Chimique Balard (ED 459) for the co-tutelle. The authors would like to thank Jelle D'helft from NourSea Calanus and Dr. von Schacky and Annick Deraedt from WHC UnoCardio for providing free samples of calanus oil and softgels of UnoCardio 100 to T.D.

\section{Conflict of interest}

The authors declare no conflict of interest.

Keywords: isoprostanes - neuroprostanes - PUFA metabolites quantification $\cdot$ total synthesis

[1] J. D. Morrow, K. E. Hill, R. F. Burk, T. M. Nammour, K. F. Badr, L. J. Roberts II, Proc. Natl. Acad. Sci. USA 1990, 87, $9383-9387$.

[2] J.-M. Galano, Y. Y. Lee, C. Oger, V. Claire, J. Vercauteren, T. Durand, M. Giera, J. C. Y. Lee, Prog. Lipid Res. 2017, 68, 83-108.

[3] a) J. Nourooz-Zadeh, E. H. C. Liu, E. E. Änggård, B. Halliwell, Biochem. Biophys. Res. Commun. 1998, 242, 338-344; b) J. Nourooz-Zadeh, B. Halli- 
well, E. E. Änggård, Biochem. Biophys. Res. Commun. 1997, 236, $467-$ 472; c) M. VanRollins, R. L. Woltjer, H. Yin, J. D. Morrow, T. J. -Montine, J. Lipid Res. 2008, 49, 995-1005.

[4] D. F. Taber, J. D. Morrow, L. J. Roberts II, Prostaglandins 1997, 53, 63-67.

[5] J. Roy, C. Oger, J. Thireau, J. Roussel, O. Mercier-Touzet, D. Faure, E. Pinot, C. Farah, D. F. Taber, J. P. Cristol, J. C. Y. Lee, A. Lacampagne, J.-M. Galano, T. Durand, J. Y. Leguennec, Free Rad. Biol. Med. 2015, 86, 269 278.

[6] J. Jamil, P. Bankhele, A. Salvi, J. E. Mannix, C. Oger, A. Guy, J.-M. Galano, T. Durand, Y. F. Njie-Mbye, S. E. Ohia, C. A. Opere, Neurochem. Res. 2014 39, 2360-2369.

[7] L. Minghetti, R. Salvi, M. Lavinia Salvatori, M. A. Ajmone-Cat, C. De Nuc cio, S. Visentin, V. Bultel-Poncé, C. Oger, A. Guy, J.-M. Galano, A. Greco, A. Bernardo, T. Durand, Free Rad. Biol. Med. 2014, 73, 41-50.

[8] U. Jahn, E. Dinca, Chem. Eur. J. 2009, 15, 58-62.

[9] U. Jahn, E. Dinca, J. Org. Chem. 2010, 75, 4480-4491.

[10] J. Smrček, R. Pohl, U. Jahn, Org. Biomol. Chem. 2017, 15, 9408-9414.

[11] C. Oger, Y. Brinkmann, S. Bouazzaoui, T. Durand, J.-M. Galano, Org. Lett. 2008, 10, 5087-5090.

[12] C. Oger, Z. Marton, Y. Brinkmann, V. Bultel-Poncé, T. Durand, M. Graber, J.-M. Galano, J. Org. Chem. 2010, 75, 1892-1897.

[13] S. H. Hwang, K. Wagner, J. Xu, J. Yang, X. Li, Z. Cao, C. Morisseau, K. S. Lee, B. D. Hammock, Bioorg. Med. Chem. Lett. 2017, 27, 620-625.

[14] H. D. Verkruijsse, L. Brandsma, Synth. Commun. 1990, 20, 3375-3378.

[15] A. Fuentes, J.-M. Marinas, J. V. Sinisterra, Tetrahedron Lett. 1987, 28, $2951-2954$.

[16] H. O. Bang, J. Dyerberg, A. B. Nielsen, Lancet 1971, 297, 1143-1146.
[17] a) J. G. Fodor, E. Helis, N. Yazdekhasti, B. Vohnout, Can. J. Cardiol. 2014 30, 864-868; b) F. Shahidi, P. Ambigaipalan, Annu. Rev. Food Sci. Technol. 2018, 9, 345-381.

[18] a) For recent studies and reports see: Oxidation in Omega-3 Oils: An Overview. A White Paper Prepared by the Global Organization for EPA and DHA Omega-3s and the Council for Responsible Nutrition, https:// www.goedomega3.com/storage/app/media/scientific-reports/Oxidation\%20in\%200mega-3\%200ils \%20An\%20Overview.pdf (July $3^{\text {rd }} 2020$ ); b) G. Bannenberg, H. B. Rice, A. Bernasconi, A. Ferrari, C. Mallon, L. Navarrete, R. Hughes, J. Lgarashif, K. Persons, L. Latynski, A. Phungi, S. Wangi, A. Ismailj, J. Food Comp. Anal. 2020, 88, 103435-103447; c) B. B. Albert, J. G. B. Derraik, D. Cameron-Smith, P. L. Hofman, S. Tumanov, S. G. Villas-Boas, M. L. Garg, W. S. Cutfield, Sci. Rep. 2015, 5, 7928-7934; d) P. D. Nichols, L. Dogan, A. Sinclair, Nutrients 2016, 8, 703-712.

[19] See the Supporting Information for more details on the composition of the edible oils and their quantification by microLC-MS/MS.

[20] C. Vigor, G. Reversat, A. Rocher, C. Oger, J.-M. Galano, J. Vercauteren, T. Durand, T. Tonon, C. Leblanc, P. Potin, Food Chem. 2018, 268, 452-462.

[21] a) C. Oger, V. Bultel-Poncé, A. Guy, T. Durand, J.-M. Galano, Eur. J. Org. Chem. 2012, 2621-2634; b) A. Guy, C. Oger, J. Heppekausen, C. Signorini, C. De Felice, A. Fürstner, T. Durand, J.-M. Galano, Chem. Eur. J. 2014, $20,6374-6380$. 